Maria J. Turos

Warszawski Uniwersytet Medyczny

ORCID 0000-0003-1343-9218

\title{
Wyżywienie i zaopatrzenie farmaceutyczne chorych i rannych żołnierzy w I8I5 roku w świetle Przepisów służby zdrowia wyjętych z ogólnego urządzenia Administracyi i Rachuby wewnętrznej dla Woyska Polskiego wszelkiej broni zatwierdzonego przez Komitet Woyskowy
}

\author{
Nutrition and Pharmaceutical Supplies for Sick and \\ Wounded Soldiers in 1815 in the Light of Healthcare \\ Provisions Extracted from the General Ordinance of the \\ Administration and Internal Account for the Polish Armed \\ Forces of all Branches Approved by the Military Committee
}

The text discusses two vital issues dealt with in the document titled Healthcare Provisions Extracted from the General Ordinance of the Administration and Internal Account for the Polish Armed Forces of all Branches Approved by the Military Committee (1815), namely the nutrition and pharmaceutical supplies for sick and wounded soldiers.

Keywords: the Kingdom of Poland, military health service, Przepisy służby zdrowia wyjęte z ogólnego urządzenia Administracyi i Rachuby wewnętrznej dla Woyska Polskiego wszelkiej broni zatwierdzone przez Komitet Woyskowy (Healthcare Provisions Extracted from the General Ordinance of the Administration and Internal Account for the Polish Armed Forces of all Branches Approved by the Military Committee)

Słowa kluczowe: Królestwo Polskie, wojskowa służba zdrowia, Przepisy służby zdrowia wyjęte z ogólnego urządzenia Administracyi i Rachuby wewnętrznej dla Woyska Polskiego wszelkiej broni zatwierdzone przez Komitet Woyskowy

Przepisy służby zdrowia wyięte z ogólnego urządzenia Administracyi i Rachuby wewnętrznej dla Woyska Polskiego wszelkiej broni zatwierdzonego przez Komitet Woyskowy są dokumentem zachowanym jednynie w zbiorach Muzeum Wojska Polskiego w Warsza- 
wie. ${ }^{1}$ Jak wskazuje nazwa, został on opracowany pod auspicjami Komitetu Wojskowego, powołanego do istnienia pod przewodnictwem wielkiego księcia Konstantego jeszcze w Paryżu w pierwszych dniach maja 1814 r. ${ }^{2}$, a który od września - pierwsze posiedzenie odbyło się dnia 27 tego miesiąca - rozpoczął swoją pracę w Warszawie 3 . Przypuszczalnie już na tym posiedzeniu, bądź też na kolejnym, dwa dni później, 30 września, Konstanty polecił jednemu z członków, a konkretnie generałowi Józefowi Wielhorskiemu „trudnić się rachunkami w komitecie wojennym i szpitalami"4. Czas, kiedy najprawdopodobniej bezpośrednio zajmowano się zagadnieniami administracyjno-gospodarczymi reorganizowanej armii, przypadł na okres od początku lutego do pierwszych dni marca 1815 r. ${ }^{5}$ i wówczas też na posiedzeniach komitetu omawiano problematykę zaprezentowaną $w$ analizowanym tutaj tekście. Pierwszy projekt dokumentu, o czym wspomina w swojej monografii poświęconej wojskowej służbie zdrowia Franciszek Giedroyć, mógł być czytany już w dniu 9 lutego 1815 r. $^{6}$, albo nawet wcześniej.

Warto w tym miejscu nadmienić, że jego zasadniczy trzon powstał przypuszczalnie jeszcze przed ukonstytuowaniem się Komitetu Wojskowego i wcześniej, niż wskazuje data opublikowania. Za bezpośredniego autora bądź zasadniczego redaktora uznać bowiem trzeba Wielhorskiego, który przy opracowywaniu go bazował na zapisach z własnych notatek, raportów oraz wydawanych poleceń służbowych powstałych w czasach, kiedy piastował godność dyrektora administracji wojennej w Księstwie Warszawskim ${ }^{7}$. W jego gestii pozostawało szpitalnictwo wojskowe, omówienie zaś podejmowanych wówczas działań, tak doraźnych, jak i planowanych, długofalowych schematów organizacyjnych, jakie czynił w tym kierunku, a szczególnie liczne cytaty z Myśli różnych do projektu ułożenia służby lekarskiej znaleźć można w pracy Juliusza Willaume ${ }^{8}$. Do przyjęcia przełomu lat 1814/15 jako czasu opracowania opublikowanej drukiem wersji dokumentu skłaniają również daty figurujące pod wzorcami dokumentów które zostały zamieszczone w zakończeniu tekstu - większość z nich podaje 1814 r. Tu przykładem może być Rapport dzienny, gdzie w nagłowku figuruje data 3 listopada 1814 r. ${ }^{9}$, a także opisane w podobny sposób dwa kolejne wzory: Rapport dziesięciodniowy (11 listopada 1814 r.) i Rapport lazaretowy z miesiąca (30 listopada 1814 r.) ${ }^{10}$. Bez daty został zamieszczony jedynie wzorzec sporządzanego co dziesięć dni raportu dywizyjnego ${ }^{11}$.

O samym wydziale zdrowia jako instytucji stanowiącej oraz normującej procedury związane z wojskową służbą zdrowia i działającej w ramach Komitetu Wojskowego wspomina Wacław Tokarz ${ }^{12}$, umieszczając jego powstanie równocześnie z podjęciem obowiąz-

1 M.J. Turos, Wojskowa służba zdrowia w Królestwie Polskim 1815-1830 w świetle aktów wykonawczych, „Kwartalnik Historii Nauki i Techniki” t. 65, 2020, nr 1 s. 119.

2 Sz. Askenazy, Ministeryum Wielhorskiego 1815-1816, Warszawa 1898, s. 2.

3 Ibid., s. 3.

4 Fr. Giedroyć, Służba zdrowia w dawnem wojsku polskim, Warszawa 1927, s. 22.

5 Sz. Askenazy, op. cit., s. 8.

6 Fr. Giedroyć, op. cit., s. 211.

7 Sz. Askenazy, op. cit., s. 1.

8 J. Willaume, Służba zdrowia Armji Księstwa Warszawskiego w przededniu kampanji 1812, Warszawa 1926, s. $10-11$

9 Przepisy służby zdrowia wyięte z ogólnego urządzenia Administracyi i Rachuby wewnętrznej dla Woyska Polskiego wszelkiej broni zatwierdzonego przez Komitet Woyskowy, Warszawa 1815, s. 77.

10 lbid., s. 78, 79.

11 Ibid., s. 80 .

12 W. Tokarz, Armja Królestwa Polskiego (1815-1830), Piotrków 1917, s. 143. 
ków Komitetu po przybyciu do kraju. Stąd trzeba przyjąć, że Przepisy służby zdrowia były jednym z pierwszych podjętych przez wydział działań legislacyjnych. Podobnie o poczynaniach tego ciała ustawotwórczego wypowiada się Wacław Męczkowski, używając o nim trochę innej nazwy a mianowicie „wydział lekarski"13 i sugerując jednoczesnie jako datę powstania analizowanego dokumentu pierwszą połowę, a najpóźniej czerwiec $1815 \mathrm{r}^{14}$

Omawiany tekst stanowi niewielką książeczkę formatu szesnastki i liczy 80 stron, w tym na 55 początkowych znajduje się zasadniczy tekst dokumentu, w zakończeniu zaś, na stronach 56-80 zamieszczony został pełen zestaw formularzy składających się ze schematów tabel, listy preparatów leczniczych oraz wzorów wspomnianych już raportów. Przypuszczalnie większość z tych ostatnich nie była oddzielnie drukowana i następnie rozsyłana do lekarzy pracujących w konkretnych szpitalach. Wskazują na to m.in. takie informacje pod tekstami raportów jak: „rapport ma bydź 1/2 arkuszowy in folio”15 bądź "1/2 arkuszowy in folio"16, stąd wniosek, że każdorazowo sporządzano je w tym miejscu, gdzie później były wypełniane. Książka została wydana została w Warszawie w drukarni Wiktora Zawadzkiego. Sam druk jest dość staranny, choć w tekście można napotkać kilkanaście usterek zecerskich m.in. w numeracji (na s. 15, 17 i 27) bądź w błędnym użyciu kursywy (s. 17), a także opuszczenie części tabeli (s. 71). W tekście znajdują się liczne wyliczenia dotyczące kosztów wyposażenia szpitala pułkowego określone mianem Tabella pierwszego sprawunku ${ }^{17}$, a także inne kosztorysy oraz tabele stanowiące bezpośrednie uzupełnienie odpowiednich ustępów, szczególnie dotyczacych zagadnień sanitarno-higienicznych (jak pranie pościeli oraz wyposażenie w sprzęty i naczynia bezpośrednio przeznaczone do użytku chorych).

Koszt dziennego utrzymania chorego w lazarecie pułkowym (ich wielkość wahała się zależnie od formacji i dla pułków piechoty wynosiła 120 łóżek, dla kawalerii - 46, dla artylerii lekkiej - 11, pozycyjnej i konnej-16, garnizonowej - 8 oraz od 7 do 4 dla jednostek specjalistycznych, takich jak saperzy, pontonierzy, minerzy bądź rzemieślnicy ${ }^{18}$, zaś w pułkach gwardii - piechoty i kawalerii - była o dwa łóżka większa niż w oddziałach liniowych) jest możliwy do oszacowania. Zdaniem Tokarza ${ }^{19}$ według ustalonych przez niego danych (niestety brak jest w tym miejscu odnośnika źródłowego) w odniesieniu do funkcjonującego (pomimo podanej w Przepisach służby zdrowia już w pierwszym rozdziale informacji że „szpitale główne ustaią"20) szpitala głównego w Warszawie koszt wynosił 1 złoty i 16 groszy, co było symą dość znacząca. Trochę inną, przy tym dużo mniejszą kwotę, wynoszącą zaledwie 26 groszy, którą należy odnieść do szpitali pułkowych, podają Wacław Męczkowski21 oraz Franciszek Giedroyć22. Wyliczenie to jest zgodne ze zsumowaniem pozycji z paragrafów 1-3, rozdziału I Wyszczególnienie funduszów na utrzymanie 
chorych ${ }^{23}$ zawartego w tytule (tj. dziale) drugim Przepisów służby zdrowia. W jej skład wchodziło: 15 groszy potrącanych z żołdu chorego żołnierza bądź podoficera, następnie 4 grosze dopłaty rządowej (była to kwota przeznaczona na „żywność i lekkie pokarmy”24 - przypuszczalnie były to dania bezmięsne przygotowywane na zlecenie lekarza), 6 groszy przeznaczonych na zakup lekarstw oraz 1 grosz na opał do sali szpitalnej.

Warto nadmienić, że z owych 4 groszy dopłaty rządowej miały być kupowane nie tylko artykuły spożywcze, ale również inne produkty opisane jako „należące do ochędostwa [tj. utrzymania porządku] wewnętrznego i światło"25, czyli świece, olej do lamp, kadzidło ${ }^{26}$, gąbki do mycia, miotły i piasek.

Nie bez znaczenia będzie też fakt, że pacjentami szpitali przypisanych do danej jednostki z założenia mieli być nie tylko żołnierze, lecz także podoficerowie wchodzący w skład tzw. mniejszego sztab pułku²7. Na tych samych zasadach leczeni byli także urzędnicy, "officyaliści przy Arsenałach i fabrykach artyllerycznych"28. Przewidziano dla nich miejsca w szpitalach artylerii garnizonowej, jakie zorganizowane zostały początkowo w Garwolinie oraz Magnuszewie ${ }^{29}$, później zaś w lazaretach zorganizowanych na terenie twierdz w Modlinie i w Zamościu ${ }^{30}$.

Spośród tabel zamykających treść dokumentu, biorąc pod uwagę to zagadnienie, warto zwrócić uwagę na pięć następujących. Pierwszą jest Tabella dyet. Stanowiła ona uzupełnienie pierwszego rozdziału tytułu trzeciego ${ }^{31}$, noszącego tytuł $O$ pokarmach i napoiach, które maią bydź dawane w Szpitalach Putkowych i onych rozdawaniu ${ }^{32}$ i liczącego dziewięć paragrafów ( $w$ tekście oryginału ostatni nie ma numeru, co przypuszczalnie jest błędem zecerskim) i noszącego tytuł $O$ pokarmach i napoiach, które maią bydź dawane w Szpitalach Putkowych, $i$ onych rozdawaniu ${ }^{33}$. Produkty spożywcze przeznaczone dla chorych, określone ogólnym mianem „pokarmy”, zostały podzielone na kilka grup a mianowicie:

a. mięso wołowe i cielęce,

b. chleb pszenny i żytni ( $w$ tym miejscu warto nadmienić, na co wskazuje zachowany w zbiorach Głównej Biblioteki Lekarskiej kwit z kwietnia 1816 r., że w szpitalach przede wszystkim podawano chleb żytni pytlowy ${ }^{34}$ (zbliżony do współczesnego

Przepisy służby zdrowia, s. 8-9.

Ibid.

lbid., s. 9.

Sale chorych w szpitalach przynajmniej raz dziennie były wykadzane. Czynność tę traktowano jako pewien sposób odkażenia powietrza. Jeśli zachowano zwyczaje z czasów Księstwa Warszawskiego, gdzie tego rodzaju postępowanie było usankcjonowane przepisami (patrz: Urządzenie Szpitalów dla Woysk Xsięstwa Warszawskiego, Warszawa 1809, s. 25: „po obiedzie lub wieczerzy wszystkie Izby powinny bydź wykadzone octem lub kadzidłem"), czynność tą wykonywano raz dziennie.

27 Sztab mniejszy był uzupełnieniem sztabu oficerskiego; w jego skład wchodzili adiutanci, starsi podoficerowie, konował (weterynarz) oraz rzemieślnicy pułkow, zob. R. Bielecki, Encyklopedia wojen napoleońskich, Warszawa 2001, s. 536. Trochę inną definicję podaje W. Męczkowski, op. cit., s. 23., zaliczając do małego sztabu peronel medyczny, kapelana i audytora (sędziego wojskowego).

Przepisy służby zdrowia, s. 11.

Fr. Giedroyć, op. cit., s. 259.

W. Męczkowski, op. cit., s. 28.

Przepisy służby zdrowia, s. 13-15.

Ibid.

Ibid.

Zbiory Specjalne Głównej Biblioteki Lekarskiej, Nr. 855. 
razowego), a białe pieczywo pszenne zaliczane było do pokarmów dietetycznych; zwracano przy tym baczną uwagę, aby chleb był dobrze wypieczony),

c. kasze: jęczmienna, tatarczana (gryczana) i drobna (niestety nie wiadomo bliżej o jaką kaszę tu chodziło, być może pszenną, typu współczesnej kaszy mannej, bądź popularnej wówczas semolinki ${ }^{35}$ albo jaglaną),

d. masło,

e. ryż,

f. mleko,

g. jajka,

h. świeża słonina (w oryginale „młoda" ${ }^{36}$, co nie pozwala ustalić, czy chodziło tu o słoninę świeżą, niesoloną, czy o słoninę z młodych świń),

i. owoce: śliwki suszone lub świeże jabłka

j. jarzyny: marchew, kartofle (tu w tekście oryginału użyty jest zwrot „i t.d." 37 , co może wskazywać, że w kuchni szpitalnej używano również innych sezonowych bądź łatwych w przechowywaniu warzyw, takich jak brukiew, groch czy fasola),

k. barszcz „burakowy"38

I. napoje (tu zostało zaliczone „wino francuzkie białe lub czerwone, piwo dubeltowe $^{39}$, wódka trzymaiąca 36 gradusów"40).

Prócz trzech napojów uwzględnionych w zestawieniu, chorzy otrzymywali jeszcze do picia „tyzannę" ${ }^{41}$, wydzielaną do jednego z dwóch kubków wymienionych w wyposażeniu jednego miejsca szpitalnego pacjenta. Była ona przygotowywana w aptece, oddzielny zaś kociołek do jej sporządzania został uwzględniony w tabeli zakupu sprzętów ${ }^{42}$. Był to napój z ziół oraz oraz suszonych owoców i liści (najbardziej popularny przygotowywano z suszonych w tym celu skórek jabłek oraz liści malin i czarnej porzeczki), podawany zamiast kawy czy herbaty. O jego wartościach zdrowotnych obszernie pisał Jacek Hiacynt Dziarkowski, przepisy zaś na nie zamieścił w swojej książce Wybór roślin kraiowych dla okazania skutków lekarskich ku użytkowi domowemu ${ }^{43}$. Innym tego rodzaju napojem, polecanym szczególnie rannym, był odwar z jęczmienia bądź owsa o konsystencji rzadkiego kleiku, zalecany przez lgnacego Fijałkowskiego ${ }^{44}$.

Zaprezentowana w aneksie do niniejszego artykułu tabela, wymieniona w tekście Przepisów służby zdrowia jako Skład porcyów, miara ich i waga iest Tabellą załączoną oznaczona ${ }^{45}$, zawierała szczegółowe przepisy dotyczące składu oraz wielkości każdego

Drobna kasza z twardej pszenicy, zob: E. Kowecka, w salonie $i$ w kuchni. Opowieść o kulturze materialnej pałąców i dworów polskich w XIX w., Poznań 2008, s. 188.

36 Przepisy służby zdrowia, s. 13.

37 Ibid.

38 Ibid. Sporządzano go z kiszonych buraków czerwonych.

39 Mocne piwo otrzymywane przez fermentację podwójnej ilości jęczmienia.

40 Tj. mająca $36 \%$.

41 Zniekształcone francuskie tisanne - napój ziołowy.

42 Przepisy służby zdrowia, s. 72.

43 J. Dziarkowski, Wybór roślin kraiowych dla okazania skutków lekarskich ku użytkowi domowemu, Warszawa 1806.

44 I. Fijałkowski, Początki chirurgii, Wrocław 1811 s. 22.

45 Przepisy służby zdrowia, s.14 
posiłku w zależności od ordynowanej przez lekarza diety, którą określano mianem całej porcji, pół porcji bądź jako ścisła, a także określała czas ich podawania.

Przewidziane dla chorych porcje były dość zróżnicowane, przy czym nie wszędzie zapisano szczegółowo ich wielkość (nie jest podane np. czy w ramch 1/2 porcji na śniadanie podawano sześć uncji pieczywa, czy też owe sześć uncji obejmowało cały posiłek łącznie z piwem i masłem), dieta ścisła zaś była praktycznie dietą płynną ze skromnym, czy nawet minimalnym - ok. 2,5 dkg - udziałem produków stałych.

W tym miejscu trzeva zaznaczyć, że po raz pierwszy tego rodzaju uszczegółowienie znaleźć można w dokumencie powstałym w 1809 r., noszącym tytuł Urządzenie Szpitalów dla Woysk Polskich Xsięstwa Warszawskiego, w liczącym 32 paragrafy rozdziale 11 noszącym tytuł $O$ pokarmie i rozdawaniu onegóż ${ }^{46}$. Określono tam m.in. rodzaje produktów oraz potraw, a także czas ich podawania, co odbywało się dwukrotnie w ciągu dnia „rano o godzinie 10-tey, a w wieczór o godzinie 4-tey"47. Przepisy te były usankcjonowane również specjalną tabelą, którą po wizycie lekarskiej i ustaleniu diety dla konkretnego chorego podpisywał chirurg dyżurny ${ }^{48}$, i w ogólnych zarysach, prócz innego dzielenia porcji (cała, 3/4 porcji, pół porcji, 1/4 porcji ${ }^{49}$ ) niewiele różniły się od tych jakie zostały wprowadzone w $1815 \mathrm{r}$.

Prócz zaleceń ogólnych funkcjonowała przypuszczalnie specjalna bardziej szczegółowa Taryffa żywności i napoiów ${ }^{50}$. Co prawda Franciszek Giedroyć łączy ją z dokumentami późniejszymi, wydanymi w 1831 r., przede wszystkim z instrukcją dotyczącą urządzenia szpitali wojskowych, ale nie można wykluczyć, czy w tej postaci nie mogła być wprowadzona już wcześniej.

Drugą z tabel dotyczących problematyki wyżywienia i - jak sugeruje umieszczona w prawym górnym rogu liera B - stanowiącą uzupełnienie poprzedniej jest Wyciąg ogólny zapisaney żywności dla Chorych pułku NN... dnia N... miesiąca N... roku N... ${ }^{51}$. Schemat tego druku został skonstruowany następująco: po nagłówku wyliczenie ścisłych porcji, pół porcji i całej porcji, następnie pokarmy nadzwyczajne, jak potrawka z cielęciny, jajka oraz polewka winna, przy czym brak jest informacji czy lekarz mógł zaordynować jeszcze jakąś potrawę dietetyczną, czy tylko wolno mu było zapisywać te wyszczególnione. Ostatnią pozycję stanowił alkohol, określony mianem „trunek”, gdzie wyróżniono wódkę podzieloną na pół i całą porcję, piwo oraz wino. Zestawienie to podpisywali wymienieni: sztabslekarz, chirurg oraz felczer pułku, przy czym brak jest dokładniejszych wskazówek, czy mógł tam figurować tylko jeden podpis. Na wzorze brak jest także adnotacji o sposobie sporządzania dokumentu, stąd można przypuszczać, że był on drukowany centralnie i rozsyłany do szpitali.

Kolejna z tabel, dotycząca interesującego zagadnienia została poświęcona w całości zaopatrzeniu farmaceutycznemu i została zatytułowana Wykaz lekarstw, które pułki piesze z Głowney Apteki maią kupować. Była to najobszerniejsza z zamieszczonych w całym

\footnotetext{
46 Urządzenie Szpitalów, s. 23.

47 Ibid.

48 Ibid., tabela nr 5 po tekście, brak paginacji.

49 Ibid., s. 23.

50 Fr. Giedroyć, op. cit., s. 251-253.

51 Przepisy służby zdrowia, s. 57.
} 
zestawieniu, licząca 7 stron ${ }^{52}$, a tworzyły ją trzy połączone ze sobą części. Po zasadniczym tekście, gdzie zamieszczono w układzie alfabetycznym surowce oraz gotowe preparaty w ilości przenaczonej na okres trzech miesięcy dla 120 chorych, znajdowało się wyszczególnienie produktów do nabywania na miejscu. Były to kolejno: ocet winny, sadło wieprzowe, jeczmień całkowity (w ziarnach), następnie miód praśny ${ }^{53}$, olej Iniany, oliwa zwyczajna i okowitka ${ }^{54}$. Pod nim jako część trzecia, został figurował spis leków do wykonywania na miejscu w aptece pułkowej. Obejmował on kolejno: Aqua Calcis ${ }^{55}$ et Goular$d i^{56}$, Aqua Phagedaenica ${ }^{57}$, Extr. Ac. Halleri ${ }^{58}$, Linimentum volatile ${ }^{59}$, Linimentum Camphoratum ${ }^{60}$, Liquor Acetas Ammoniae ${ }^{61}$, Spiritus Camphoratus, Oxymel siplex ${ }^{62}$ et Squillae ${ }^{63}$, Syropus communis ${ }^{64}$, Pulveres varii ${ }^{65}$.

W tym miejscu trzeba nadmienić, że zgodnie z paragrafem 14 tytułu pierwszego Urządzenia ogólne ${ }^{66}$ oraz 3 rozdziału IV, zatytułowanego $O$ aptekach pułkowych ${ }^{67}$ sporządzaniem tych specyfików oraz innych, określonych mianem „kompozycjów”68, miał zajmować się „podchirurg w pułku będący”, czyli felczer pułkowy pod nadzorem sztabslekarza, gdyż oddzielny etat dla farmaceuty $w$ szpitalu danej jednostki nie został przewidziany i przez cały ten czas pełną obsadą farmaceutyczną o właściwych kwalifikacjach dysponowała wyłącznie Apteka Główna w Warszawie. Według „Rocznika Woyskowego na 1817 rok” pracowali w niej Stanisław Kościelski, Jan Żelazowski, Andrzej Ziembiński, Franciszek Gadomski oraz dwaj praktykanci: Ludwik Ziegler i Jan Gorecki ${ }^{69}$. W 1820 r. jej pracownikami byli: Stanisław Kościelski, Jan Żelazowski, Franciszek Gadomski i Jan Ziembiński70. W związku z tym w aptece szpitalnej, zwłaszcza jednostki stacjonującej daleko od dużego miasta, była to osoba z minimalnym przygotowaniem fachowym, tym bardziej, że w zakończeniu paragrafu 2 można przeczytać dość lakoniczny zwrot: „sztabslekarz wybiera sobie do pomocy zdatnego cerulika i posługacza"71. Naczelny sztabslekarz wojska polskiego Jan Stummer wkrótce po ukazaniu się Przepisów służby zdrowia określił co prawda prerogatywy zawodowe felczerów: „powinni umieć czytać i pisać po polsku oraz nieco po łacinie

52 Ibid., s. 58-64.

53 Przaśny, surowy; nie można wykluczyć błędu zecerskiego.

54 Mocna wódka.

55 Woda wapienna, używana w przypadku oparzeń. Dane farmaceutyczne za: L. Augustin, Pharmacopoea extemporanea exhibens compositiones medicamentorum, Berlin 1809.

56 Tzw. woda Goularda, roztwór octanu ołowiu używany do okładów w przypadku kontuzji.

57 Sól rtęciowa, jeden z preparatów stosowanych w leczeniu choró wenerycznych.

58 Słaby wodny roztwór kwasu siarkowego stosowany jako środek pobudzający apetyt.

59 Mazidło na bazie amoniaku o działaniu cucącym i pobudzającym.

60 Mazidło kamforowe, środek rozgrzewający.

61 Dokładnie Liquor Ammonii acetici, środek pobudzający.

62 Miód octowy, specyfik przygotowywany z octu jabłkowego i miodu, podłoże dla wielu ziołowych substancji leczniczych.

63 Miód z cebuli morskiej, lek nasercowy.

64 Prosty syrop z cukru

65 Proszki rozmaite.

66 Przepisy służby zdrowia, s. 6.

67 Ibid., s. 45.

68 Ibid.

69 „Rocznik Woyskowy na rok 1817”, s. 168

70 Lista osób leczeniem i lekarstwami trudniących się w Królestwie Polskim w roku 1820, br. m. i r. wyd., s. 26. Zachowany egzemplarz w zbiorach Biblioteki PAN w Kórniku, sygn. 214590.

71 Przepisy służby zdrowia, s. 6 
umieć powinni, tudzież posiadać zręczność do opatrywania i chodzenia około chorych"72, lecz należy mieć wątpliwości, czy te kwalifikacje posiadali wszyscy, jak również, czy owa minimalna znajomość języka łacińskiego wystarczała do zrozumienia receptury.

Następna z tabel poświęcona zaopatrzeniu farmaceutycznemu to Wykaz lekarstw które pułki Konne z Apteki Główney maią kupować. Tekst jest jednobrzmiący z prezentowanym powyżej, przy czym ilości są zmniejszone proporcjonalnie do wielkości szpitala - na 46-50 chorych (choć w rubryce podana jest „jlość na kwartał przeznaczona jest na 120 cho..."73, co trzeba uznać za błąd zecerski). Brak w nim jedynie ostatniej pozycji, czyli spisu leków do przygotowywania na miejscu. Trudno ustalić, czy nie jest to również usterka zaistniała w czasie składania tekstu.

Pierwowzorem dla obu powyższych druków był przekład na język polski formularza obowiązującego w służbie zdrowia wojsk napoleońskich - Formulaire pharmaceutique a l'usage des hôpitaux militaires ${ }^{74}$ - w przystosowany, o czym autorzy tłumaczenia informują na karcie tytułowej, dla potrzeb oraz warunków panujących na terenie Polski. Został on zamieszczony w opublikowanych w 1810 r. książce Przepisach lekarstw dla szpitalów Woyska Polskiego ${ }^{75}$. Tekst ten od samego początku wzbudzał negatywną opinię w oczach Wielhorskiego, który w drugiej połowie 1812 r., kierując swoje zapytanie do wydziału lekarskiego Akademii Krakowskiej, sugerował opracowanie nowej farmakopei. Prośbę motywował dopasowaniem receptur do najposplitszych schorzeń występujących wśród żołnierzy, oszacowanych na podstawie raportów szpitalnych, maksymalnym uproszczeniem procedury przygotowania leków, wprowadzeniem takich technik preparowania, aby „położyć tamę nadużyciom i niewierności laborantów"76, oraz zastąpieniem szeregu surowców sprowadzanych z zagranicy tańszymi krajowymi i wprowadzeniem takiej kalkulacji, by „jak najmniej leków drogich przepisywać"77. Warto w tym miejscu zaznaczyć, na co zwracał również uwagę w swojej pracy Giedroyć, że ów list intencyjny nie został podpisany, więc nie można mieć pewności co do jego bezpośredniego autorstwa ${ }^{78}$.

Jest zastanawiające, dlaczego Wielhorski, jeśli planował zmiany w tekście Przepisów lekarstw, nie wykorzystał do przygotowania nowego formularza i zestawu leków dla szpitali wojskowych farmakopei ułożonej przez Jacka Hiacynta Dziarkowskiego i wydanej w Warszawie w 1794 r., Pharmacopoea castrensis et nosocomialis ${ }^{79}$. Doskonale nadawała się do tej roli, gdyż wyróżniał ją niewielki format i objętość - liczyła 32 strony druku a ponadto posiadała czytelny układ z podziałem na trzy części. Kolejno były to: Materia medica ${ }^{80}$, w której zostały wymienione surowce farmaceutyczne: roślinne, pochodzenia zwierzęcego i mineralne oraz preparaty chemiczne jak eliksiry, ekstrakty i plastry, następ-

72 Archiwum Główne Akt Dawnych, Warszawa Komisja Rządowa Wojny Seria 5 Nr. 193 Dyrekcja I Wydział II Wydział Zdrowia versus Lekarski, Sztab Główny. Główne Dyżurstwo Seria 17.

73 Przepisy służby zdrowia, s. 65.

74 Formulaire pharmaceutique a I'usage des hôpitaux militaires, Paris An. XIII (1804), s. 91-102.

75 Przepisy lekarstw dla szpitalów Woyska Polskiego. Dzieło tłomaczone z języka francuzkiego, Warszawa 1810.

76 J. Willaume, op. cit., s. 9

77 lbid.

78 Fr. Giedroyć, op. cit., s. 273.

79 Pharmacopoea castrensis et nosocomialis exercitus nationalis, Varsoviae 1794 (reprint Kraków 2010).

80 Ibid., s. $1-5$. 
nie Preparata et composita ${ }^{81}$, gdzie w układzie alfabetycznym przedstawione zostały 94 recepty na wszystkie najważniejsze środki lecznicze (jedyną usterką był tu brak miar ilości substancji wchodzących w skład danego specyfiku), i wreszcie Index morborum ${ }^{82}$, w którym również alfabetycznie zaprezentowano jednostki chorobowe oraz odpowiednio dobrane do nich lekarstwa. Trudno przypuszczać, by farmakopea ta nie była generałowi znana. Tym bardziej zastanawia, że nie zwrócił się z zapytaniem bądź propozycją ułożenia rozszerzonego, unowocześnionego i ewentualnie uwzględniającego jego sugestie dzieła bezpośrednio do autora tekstu, który przebywał w tym czasie w Warszawie, gdzie pełnił obowiązki dziekana Szkoły Medycznejes.

Podobnie może budzić zastanowienie fakt, że generał nie skierował swojej propozycji stworzenia nowej farmakopei wojskowej do związanego również ze Szkołą Medyczną w Warszawie Józefa Celińskiego, autora opublikowanej w 1811 r. dwuczęściowej Farmacyi czyli nauki doskonałego przyrządzania lekarstw z trzech królestw natury wybranych ${ }^{84}$. Było to dzieło bardzo obszerne, liczące w sumie ponad 800 stron, lecz z całą pewnością autor dokonałby w nim niezbędnych skrótów i ten typowo akademicki, szczegółowy podręcznik zaadaptował do potrzeb lekarzy oraz farmaceutów wojskowych.

W tym samym czasie powstawały również dwa dzieła Jana Bogumiła Freyera, a mianowicie Formulare, czyli Nauka o sztucznem przepisywaniu lekarstw ${ }^{85}$, w którym zawarł blisko 306 gotowych recept, oraz Materia medyczna czyli nauka o sposobie skutkowania śrzodków lekarskich ${ }^{86}$, więc i do niego mógł zwrócić się Wielhorski z prośbą o przygotowanie na ich podstawie odpowiedniego formularza farmaceutycznego dla wojska polskiego. Szczególnie pierwsza z tych prac świetnie nadawała się do tego celu. Została napisana, na co zwracał uwagę Józef Bieliński ${ }^{87}$, bardzo przystępnym językiem. Liczyła zaledwie 237 stron (receptura - 110), miała niezwykle czytelny układ, zawierała szczegółowy podział na leki stałe i płynne, oraz 306 recept z podanymi ilościami substancji, czego brakowało w pracy Jacka Hiacynta Dziarkowskiego, czyli byłby to doskonały materiał do konstrukcji podobnego dzieła dla wojska.

Brak farmakopei adresowanej do farmaceutów wojskowych wyraźnie koliduje z paragrafem 20 tytułu VI O urządzeniu Apteki Głowney woyskowey ${ }^{88}$, gdzie wyraźnie zostało zapisane:

prowizor, przy pomocy Adjunkta wyrabia preparata przepisane w dyspensatoryum $^{89}$ kraiowem, i pod odpowiedzialnością ma mieć w każdym czasie onych tyle, ile będzie potrzeba na kwartalne zaopatrzenie pułków ${ }^{90}$.

81 Ibid., s. 6-20.

82 Ibid., s. 21-32.

83 M. Turos, „...po Historii błądząc...”, [w:] Senat. Historia i współczesnośc najważniejszego ciała kolegialnego uczelni, red. M. Zielonka, M J. Turos, M. Krawczyk, Warszawa 2013, s. 10-13.

84 J. Celiński, Farmacya czyli nauki doskonałego przyrządzania lekarstw z trzech królestw natury wybranych, t. 1-2, Warszawa 1811.

85 J.B. Freyer, Formulare, czyli Nauka o sztucznem przepisywaniu lekarstw, Warszawa, 1816.

86 Idem, Materia medyczna czyli nauka o sposobie skutkowania śrzodków lekarskich, Warszawa 1817.

87 T. Ostrowska, Powstanie i rozwój wydziału Akademicko-Lekarskiego Warszawskiego, [w:] Dzieje nauczania medycyny i farmacji w Warszawie (1789-1950), red. M. Łyskanowski, A. Stapiński, A. Śródka, Warszawa 1990, s. 79.

88 Przepisy służby zdrowia, s. 48-53.

$89 \mathrm{Tj}$. spisie leków, poprzedniku farmakopei.

90 Przepisy służby zdrowia, s. 52 
Trudno ustalić, o jaką pozycję chodziło autorom tego ustępu i z czego miał korzystać farmaceuta w czasie wykonywania swoich codziennych obowiązków. Oficjalna farmakopea Królestwa Polskiego powstała dopiero w 1817 r. ${ }^{91}$, czyli już w czasie obowiązywania Przepisów służby zdrowia. Wszystko więc wskazuje, że jednak sięgano do Przepisów lekarstw dla woysk polskich Xięstwa Warszawskiego. Nie można wykluczyć, czy nie korzystano również z Pharmacopeia castrensis Ruthena, autorstwa Jamesa Wylie ${ }^{92}$, której pierwsze wydanie ukazało się w Petersburgu w 1808 r. Wiele działań mających na celu unifikację polskich i rosyjskich przepisów wojskowych ${ }^{93}$, jakie były podejmowane w czasie powstawania Przepisów służby zdrowia, mogło i tu znaleźć swoje praktyczne odniesienie.

Działania, jakie zamierzał podjąć Wielhorski bądź jakie były dokonywane na jego zlecenie, widać również w konstrukcji wykazów zamieszczonych w tabeli. Są one zdecydowanie krótsze, gdyż w Pharmacopoea castrensis et nosocomialis z 1794 r. lista odpowiadająca temu zestawieniu w Materia medica obejmuje 194 pozycje, w Przepisach lekarstw wydanych w 1810 r. jest dłuższa i liczy ogółem 235 pozycji ułożonych z zachowaniem ówczesnych prawideł aptekarskich na surowce roślinne, mineralne oraz pochodzenia zwierzęcego i podzielonych dodatkowo na lekarstwa proste ${ }^{94}$, a także złożone ${ }^{95}$, w analizowanym zaś zestawieniu jest ich zaledwie $140^{96}$ ułożonych alfabetycznie, przy czym lista ma charakter wyraźnie handlowo-rozliczeniowy - w odpowiednich rubrykach: „ilość na kwartał przeznaczona i cena ogólna"97. Pewne kategorie środków leczniczych zostały w niej uszczuplone w stosunku do listy z 1810 r. i są to m.in. gotowe mieszanki ziołowe, których liczba zmalała z 9 do 5, a następnie plastry - z 10 do 6. Podobnie działo się z wyciągami leczniczymi, gdyż z 9 jakie podaje lista z Przepisów lekarstw ${ }^{98}$, w nowym zestawieniu zachowane zostały tylko 4, oraz z ekstraktami, których, co warto odnotować, w Pharmacpoea extemporanea z 1794 r. wymienionych zostało 799, w Przepisach lekarstw z 1810 r. - 6 600, a w 1815 r. - zaledwie jeden, a mianowicie Extractum Amarum, czyli mieszanka ziół gorzkich, m.in. mięty pieprzowej i piołunu, stosowana przy problemach trawiennych ${ }^{101}$. Przewidziano go w sumie dość dużo, gdyż porcja kwartalna tego specyfiku wynosiła 3 funty $(1,35 \mathrm{~kg}$.), a dla leku w postaci płynnej ok. 1,3 litra.

Prócz szeregu ograniczeń ilościowych paragrafy 3-6 rozdziału II Przepisów służby zdrowia, zatytułowanego $O$ służbie lekarsiey w Szpitalach pułkowych ${ }^{102}$, nakładały na lekarzy obowiązek używania podczas terapii tylko leków sporządzanych z surowców zamieszczonych w tabeli, każdorazowe zaś rozszerzenie czy zastosowanie innego specyfiku wymagało zgłoszenia do naczelnego lekarza dywizji. Mógł on również sam wprowadzić pewne zmiany, lecz z braku szczegółowej wykładni przypuszczalnie poruszał się również

91 Pharmacopoeia Regni Poloniae, auctoritate ministerii administrationis rerum internarum et disciplinae publicae edita, Warszawa 1817.

92 J. Wylie, Pharmacopoeia castrensis Ruthena, Petropoli 1808.

93 B. Gembarzewski, Wojsko Polskie. Królestwo Polskie 1815-1830, Warszawa 1903, s. 47-48.

94 Przepisy lekarstw, s. 120

95 Ibid., s. 125

96 Przepisy służby zdrowia, s. 63.

97 lbid.

98 Przepisy lekarstw, s. 127

99 Pharmacopea extemporanea, s. 4

100 Przepisy lekarstw, s. 126

101 Przepisy służby zdrowia. s.60.

102 Ibid., s. 37-38. 
tylko w obrębie danego schematu. W rzeczywistości obniżało to koszty, ale bez wątpienia wpływało na przebieg kuracji, a nawet jej odległe skutki. Należy więc zgodzić się z opinią Tokarza, że pomimo szczegółowych przepisów obowiązujących służbę zdrowia i dość sporych nakładów oraz wprowadzenia specjalnym rozkazem obowiązku szczepienia ospy u wszystkich rekrutów ${ }^{103}$, globalny stan zdrowotności armii pozostawiał wiele do życzenia, choroby zaś, szczególnie epidemiczne, zdarzały się dość często ${ }^{104}$. Jedną z plag, prócz dolegliwości przewodu pokarmowego i biegunek ${ }^{105}$, było zapalenie oczu, z którym borykał się m. in. lekarz dywizyjny dr. Fryderyk Szwencki, łącząc tą przypadłość z fatalnymi warunkami, w jakich kwaterowali żołnierze, przede wszystki ciasnymi, wilgotnymi oraz mało wietrzonymi pomieszczeniami, szczególnie na terenie twierdz Modlin i Zamość. Pisał o tym w szczegółowym raporcie do generała Wincentego Krasińskiego ${ }^{106}$, podając jednocześnie sposób postępowania leczniczego polegający na stosowaniu specjalnych maści, w tym jednej własnej kompozycji, częstym przemywaniu oczu zimną wodą, po ustąpieniu zaś zasadniczych objawów - przebywaniu poza koszarami „na kwaterze”107. Manewry przeprowadzane $w$ miesiącach zimowych skutkowały licznymi odmrożeniami, forsowne ćwiczenia zaś, szczególnie artyleryjskie, prowadzone w trudnych warunkach polowych sprzyjały też dużej liczbie ciężkich i trwale okaleczających urazów ${ }^{108}$.

Rozliczenie zużycia lekarstw ewidencjonowane było na specjalnym formularzu. Został on opatrzony nagłowkiem Wykaz zapisanych lekarstw z dnia lub Miesiąca iednego wyciągnięta z kartek wizytnych ${ }^{109}$, czyli zsumowana ze specjalnych kart wypełnianych przez lekarza podczas porannej wizyty, których wzór również został zamieszczony w zestawie ${ }^{110}$. Występujące w tabeli słowo „relewa” oznaczające ilość dawek - w tekście użyte zostało słowo „dozy" - danego specyfiku użytych w określonym czasie na wiele lat weszło do potocznego żargonu szpitalnego i oznaczało dzienne zapotrzebowanie dla oddziału na leki oraz posiłki dla pacjentów ${ }^{111}$.

Jest rzeczą ciekawą, że w tym wzorze - bo za taki należy go uznać, biorąc pod uwagę adnotację o sposobie przygotowania wersji oficjalnej: „wzór ten zapisuje się na 1/2 arkuszu poprzecznie"112 - zostały w pozycji „relewa” wymienione specyfiki, jakie mogły być przygotowywane na miejscu, w aptece pułkowej.

Generalnie o stanie zdrowia, a raczej o chorobach, jakie podówczas były rozpoznawane i opisywane, mówiła ostatnia z tabel, opatrzona nagłowkiem Rapport z miesiąca całego [w tekście oryginału podano listopada] wyrażaiący liczbę dni lazaretowych i gatunki chorób $^{113}$. Druk ten podzielony był na dwie części. Pierwsza dotyczyła schorzeń wewnętrznych, gdzie zostały wymienione kolejno: febris gastrica (nieżyt żołądka), catharralis (infekcje typu

103 W. Męczkowski, op. cit., s. 32.

104 W. Tokarz, op. cit., s. 146.

105 J. Patelski, Wspomnienia wojskowe z lat 1823-1831, Wilno, 1921, s. 34.

106 W. Męczkowski, op. cit., s. 32.

107 Ibid., s. 32.

108 S. Jabłonowski, Wspomnienia o bateryi pozycyjnej artyleryi konnej gwardii królewsko-polskiej, Kraków 1916,

s. 17

109 Przepisy służby zdrowia, s. 76.

110 lbid., s. 74. Szerzej na ten temat zob. M.J. Turos, Wojskowa służba zdrowia w Królestwie Polskim, s. 119.

111 Rozmowa z prof. Bożeną Urbanek - informacja własna.

112 Przepisy służby zdrowia, s.76.

113 lbid., s. 79. 
przeziębienia), rheumatica (dolegliwości reumatyczne), biliosa (ostre zapalenie wątroby i inne schorzenia przebiegające z zółtaczką) ${ }^{114} \mathrm{i}$ jako ostatnie nervosa (termin odnoszący się do różnych postaci durów, przede wszystkim osutkowego). Druga część natomiast obejmowała urazy i zranienia. Kolejno wymienione zostały: erisipelas (róża, zakaźna choroba skóry), ulcera (wrzody) oraz vulnera (rany). Nie uwzględniono w tym zestawieniu chorych na świerzb i wenerycznie, stąd trudno orzec, czy nie byli ewidencjonowani oddzielnie.

Choroby weneryczne, szczególnie po 1817 r., o czym wspomina w swojej pracy Giedroyć ${ }^{115}$, były traktowane jako zagadnienie mało istotne i chorzy na nie musieli przebywać w koszarach, co tylko sprzyjało ich rozprzestrzenianiu się, na co zwracał uwagę generał Jan Kanty Sierawski, pisząc o „wenerycznych, którzy używając trunków szkodliwych i dopuszczając się zdrożnego życia czego upilnować niepodobna, staną się nieuleczalnymi i rozszerzać będą zarazę"116.

Trudno jest oceniać jednoznacznie tekst sprzed ponad dwustu lat. Zgodzić się trzeba z opinią Tokarza ${ }^{117}$, że kondycja żołnierzy armii Królestwa Polskiego pozostawiała wiele do życzenia. Wynikało to z całego szeregu przyczyn, które można określić mianem pozamerytorycznych. Widać to również i prezentowanym dokumencie, chociażby w ograniczeniu dostępności pewnych leków. Ogólnie jednak, starano się wprowadzić w życie zasady higieny i zapewnić chorym czy kontuzjowanym żołnierzom przyzwoite warunki bytowe oraz możliwość powrotu do zdrowia.

\section{Aneks}

Tabella dyet, Przepisy służby zdrowia, s. 56

\begin{tabular}{|c|c|c|c|c|}
\hline \multicolumn{5}{|c|}{ TABELLA DYET } \\
\hline $\begin{array}{c}\text { Znaki } \\
\text { porcjów }\end{array}$ & $\begin{array}{c}\mathrm{Na} \\
\text { Śniadanie }\end{array}$ & $\begin{array}{c}\mathrm{Na} \\
\text { obiad }\end{array}$ & $\begin{array}{c}\mathrm{Na} \\
\text { kolacyą }\end{array}$ & UWAGI \\
\hline $\begin{array}{l}\text { S } \\
\text { ścisła }\end{array}$ & $\begin{array}{l}\text { Zupa wodzian- } \\
\text { ka*, lub barsz- } \\
\text { czyku burakowe- } \\
\text { go pół kwarty } \\
\text { [0. } 47 \text { I] z pół } \\
\text { łotem [6,3 g] } \\
\text { chleba białego, } \\
\text { pszennego }\end{array}$ & $\begin{array}{l}\text { Rosół wołowy } \\
\text { z chleba białego } \\
\text { łutem jednem } \\
{[12.6 \mathrm{~g}], \text { lub }} \\
\text { tyleż kaszy } \\
\text { drobney }\end{array}$ & $\begin{array}{l}\text { Zupa } \\
\text { wodzianka } \\
\text { tak jak na } \\
\text { śniadanie }\end{array}$ & $\begin{array}{l}\text { Waga i miara iest uważana } \\
\text { pospolita kraiowa**. } \\
\text { Śniadanie i kolacyą zaraz } \\
\text { po wizycie chorym dawać } \\
\text { będą. } \\
\text { Obiad w samo południe. } \\
\text { Wino przepisuie się od- } \\
\text { dzielnie, na porcyą iedną } \\
\text { rachować kwaterkę } \\
\text { [ok. } 0,23 \text { l]. }\end{array}$ \\
\hline
\end{tabular}

114 J. Krzyś, Służba zdrowia wojsk polskich w latach 1806-1807, Grudziądz 2011, s. 36.

115 Fr. Giedroyć, op. cit., s. 209.

116 Ibid.

117 W. Tokarz, op. cit., s.145. 


\begin{tabular}{|c|c|c|c|c|}
\hline $\begin{array}{l}1 / 2 \\
\text { pół } \\
\text { porcji }\end{array}$ & $\begin{array}{l}\text { Piwa grzanego } \\
\text { z masłem i chle- } \\
\text { bem pięknym } \\
\text { żynym uncji } 6 \\
\text { [ok. 170-198 g] }\end{array}$ & $\begin{array}{l}\text { Krupniku pół } \\
\text { kwarty }[0,47 \text { I] } \\
\text { i mięsa ćwierć } \\
\text { funta [ok. } 110 \\
\text { g]. Jarzyny } \\
\text { niekiszoney } \\
\text { grubszey*** pół } \\
\text { kwarty }[0,47 \text { I] } \\
\text { z masłem }\end{array}$ & $\begin{array}{l}\text { Krupniku } \\
\text { dosyć } \\
\text { gęstego } \\
\text { pół kwarty } \\
{[0,47 \text { I] }}\end{array}$ & $\begin{array}{l}\text { Wódka lub piwo przepi- } \\
\text { sane obok dyety, w którey } \\
\text { skład nie wchodzi osob- } \\
\text { nym znakiem W. lub P. } \\
\text { oznacza się } \\
\text { Oprócz artykułów po- } \\
\text { karmowych i trunków } \\
\text { w porcyach szczególnych } \\
\text { wyrażonych przepisywane }\end{array}$ \\
\hline C. P. & $\begin{array}{l}\text { Wódki uncyj trzy } \\
\text { [85 g] i chleba } \\
\text { żytnego pół fun- } \\
\text { ta [ok. } 200 \mathrm{~g} \text { ] }\end{array}$ & $\begin{array}{l}\text { Kaszy iakiejkol- } \\
\text { wiek iak w pół } \\
\text { porcyi - mięsa } \\
\text { i chleba po fun- } \\
\text { cie [ok. } 400 \mathrm{~g} \text { ] } \\
\text { całym }\end{array}$ & $\begin{array}{l}\text { Jak } \\
\text { w półporcyi } \\
\text { i chleba pół } \\
\text { fónta [ok. } \\
200 \mathrm{~g} \text { ] }\end{array}$ & $\begin{array}{l}\text { od Lekarza bydź mogą; } \\
\text { potrawka cielęca z } 1 / 2 \text { funta } \\
\text { [ok. } 200 \mathrm{~g} \text { ] } \\
\text { winna polewka z kwaterki } \\
\text { wina [ok } 0.23 \mathrm{I} \text { ] } \\
\text { jabłka duszone czyli kom- } \\
\text { put z } 3 \text { sztuk } \\
\text { ryżu z mlekiem z } 3 \text { uncyi } \\
\text { [ok. } 85 \text { g] ryżu) } \\
\text { jay miękich N. 1, 2, 3... }\end{array}$ \\
\hline
\end{tabular}

* Najczęściej była to zupa z chleba, sporządzana z białego pieczywa gotowanego z czosnkiem i wodą bądź słabym wywarem z jarzyn. Za: W. Wielądko, Kucharz doskonały w wybornym guście z oszczędnością dogodny, czyli sposób gotowania różnych potraw z mięsa i ryb [...] dla wygody obywateli i obywatelek gospodyń do druku podany, Warszawa 1808, paginacja uszkodzona. Jest to też danie regionalnej kuchni śląskiej.

** Wagi obowiązującena terenie Królestwa Polskiego: funt, tzw. warszawski - 0,405 kg, uncja - od 0,028 do ok. $0,033 \mathrm{~kg}$, łut $-12,65 \mathrm{~g}$. Objętości płynów: kwarta (4 kwaterki) - 0,9422 I, kwaterka - 0,235 I. Za: Tabele dawnych jednostek miar stosowanych na terenie Polski. Warszawa 2003.

*** Trudno jest ustalić, o jaką jarzynę tu chodzi, mogła to być m.in. brukiew, marchew, fasola bądź buraki. Słowo "niekiszoney” wyklucza z tego zestawu kiszoną kapustę.

\section{Bibliografia}

\section{Źródła archiwalne}

Archiwum Główne Akt Dawnych, Warszawa Komisja Rządowa Wojny Seria 5 Nr. 193 Dyrekcja I Wydział II Wydział Zdrowia versus Lekarski, Sztab Główny. Główne Dyżurstwo Seria 17. Zbiory Specjalne Głównej Biblioteki Lekarskiej, Nr. 855.

\section{Źródła drukowane}

Augustin L., Pharmacopoea extemporanea exhibens compositiones medicamentorum, Berlin 1809.

Celiński J., Farmacya czyli nauki doskonałego przyrządzania lekarstw z trzech królestw natury wybranych, t. 1-2, Warszawa 1811.

Dziarkowski J., Wybór roślin kraiowych dla okazania skutków lekarskich ku użytkowi domowemu, Warszawa 1806.

Formulaire pharmaceutique a l'usage des hôpitaux militaires, Paris An. XIII (1804).

Freyer J.B., Formulare, czyli Nauka o sztucznem przepisywaniu lekarstw przez Jana Bogumiła Freyera, Warszawa 1816. 
Freyer J.B., Materia medyczna czyli nauka o sposobie skutkowania śrzodków lekarskich, Warszawa 1817.

Lista osób leczeniem i lekarstwami trudniących się w Królestwie Polskim w roku 1820, br. m. i r. wyd.

Patelski J., Wspomnienia wojskowe z lat 1823-1831, Wilno 1921.

Pharmacopoea castrensis et nosocomialis exercitus nationalis, Varsoviae 1794 (reprint Kraków 2010).

Pharmacopoeia Regni Poloniae, auctoritate ministerii administrationis rerum internarum et disciplinae publicae edita, Warszawa 1817.

Przepisy lekarstw dla szpitalów Woyska Polskiego. Dzieło tłomaczone z języka francuzkiego, Warszawa 1810.

Przepisy służby zdrowia wyięte z ogólnego urządzenia Administracyi i Rachuby wewnętrznej dla Woyska Polskiego wszelkiej broni zatwierdzonego przez Komitet Woyskowy, Warszawa 1815.

„Rocznik Woyskowy na rok 1817".

Urządzenie Szpitalów dla Woysk Xsięstwa Warszawskiego, Warszawa 1809.

Wielądko W., Kucharz doskonały w wybornym guście z oszczędnością dogodny, czyli sposób gotowania różnych potraw z mięsa i ryb [...] dla wygody obywateli i obywatelek gospodyń do druku podany, Warszawa 1808.

Wylie J., Pharmacopoeia castrensis Ruthena, Petropoli 1808.

\section{Literatura przedmiotu}

Askenazy Sz., Ministeryum Wielhorskiego 1815-1816, Warszawa 1898.

Bielecki R., Encyklopedia wojen napoleońskich, Warszawa 2001.

Gembarzewski B., Wojsko Polskie. Królestwo Polskie 1815-1830, Warszawa 1903.

Giedroyć Fr., Służba zdrowia w dawnem wojsku polskim, Warszawa 1927.

Jabłonowski S., Wspomnienia o bateryi pozycyjnej artyleryi konnej gwardii królewskopolskiej, Kraków 1916.

Kowecka E., W salonie $i$ w kuchni. Opowieść o kulturze materialnej pałąców i dworów polskich w XIX w., Poznań 2008.

Krzyś J., Służba zdrowia wojsk polskich w latach 1806-1807, Grudziądz 2011.

Męczkowski W., Służba zdrowia w wojsku polskim, [w:] Pierwszy zjazd poświęcony polskiej medycynie wojskowej, Warszawa 1917

Ostrowska T., Powstanie i rozwój wydziału Akademicko-Lekarskiego Warszawskiego, [w:], Dzieje nauczania medycyny i farmacji w Warszawie (1789-1950), red. M. Łyskanowski, A. Stapiński, A. Śródka, Warszawa 1990.

Senat. Historia $i$ współczesnośc najważniejszego ciała kolegialnego uczelni, red. M. Zielonka, M.J. Turos, M. Krawczyk, Warszawa 2013.

Tabele dawnych jednostek miar stosowanych na terenie Polski, Warszawa 2003.

Tokarz W., Armja Królestwa Polskiego (1815-1830), Piotrków 1917.

Turos M.J., Wojskowa służba zdrowia w Królestwie Polskim 1815-1830 w świetle aktów wykonawczych, "Kwartalnik Historii Nauki i Techniki” t. 65, 2020, nr 1, s. 117-131, DOI 10.4467/0023589XKHNT.20.007.11623.

Willaume J., Służba zdrowia Armji Księstwa Warszawskiego w przededniu kampanji 1812, Warszawa 1926. 
Maria J. Turos jest doktorem nauk medycznych, magistrem teologii, filozofem i etykiem, pracownikiem naukowym Warszawskiego Uniwersytetu Medycznego. Zajmuje się historią medycyny wojskowej przełomu XVIII i XIX w. Z zamiłowania jest rekonstruktorem historycznym w wymiarze naukowym takich działań. e-mail: maria.turos@wum.edu.pl

Data zgłoszenia artykułu: 14 października 2019

Data przyjęcia do druku: 6 marca 2020 